\title{
A RE-EXAMINATION OF THE IGNIMBRITE AT FOND ST. JEAN, DOMINICA
}

NOLAN EBNER, Macalester College

Research Advisors: Holli Frey, Union College and Karl Wirth, Macalester College

\section{INTRODUCTION AND PREVIOUS WORK}

With nine potentially active volcanic centers and a history that includes some of the largest explosive eruptions in the Caribbean, the island of Dominica is widely regarded as being vulnerable to considerable volcanic hazards. Detailed knowledge of the frequency, magnitude, and distribution of volcanic eruptions is central to hazard assessment and risk mitigation on the island. Stratigraphic and geochemical fingerprinting of volcanic deposits is essential for unravelling the complex eruptive history of Dominica and understanding local volcanic hazards.

Past studies have identified five main ignimbrite depositing events on Dominica: Grand Savanne (22.2 ka; Sparks et al., 1980), Layou (79.7 ka \pm 4.8 ka; Howe et al., 2014), Grand Bay (43 ka \pm 13 ka; Frey et al., 2016), Roseau (29.343 ka $\pm 362 \mathrm{ka}$; Lindsay et al., 2005), and Grand Fond (27.6 ka \pm 0.6 ka; Carey and Sigurdsson, 1980). An ignimbrite at Fond St. Jean (38.9 ka $\pm 0.4 \mathrm{ka}$; Lindsay et al., 2005) has previously been associated with the Grand Bay ignimbrite (Lindsay et al., 2003), however significant mineralogical differences and an intervening ridge call this supposition into question (Smith et al., 2013; Boudon et al., 2017) but a detailed study of Fond St. Jean has yet to be completed. Exposures of the Grand Bay ignimbrite, along the southern coast and approximately $1.5 \mathrm{~km}$ inland, reveal it as a massive 9-14 meter thick unconsolidated coarse grained deposit. In this study I address two main goals related to the ignimbrite at Fond St. Jean:
1. Provide a detailed characterization of the ignimbrite at Fond St. Jean.

2. Determine the nature of the relationship between the ignimbrites at Fond St. Jean and Grand Bay.

Below we describe new stratigraphic measurements, petrographic analyses, and mineral and whole rock geochemical data that indicate that the ignimbrites at Fond St. Jean and Grand Bay are significantly dissimilar as to suggest that they originated from separate eruptive events.

\section{METHODS}

\section{Field}

The study area focuses on the ignimbrite and immediately underlying stratigraphic units exposed at Fond St. Jean. We measured a section at Fond St. Jean using an improvised four meter long Jacob's staff. Descriptions of the ignimbrite build on the previous work of Lindsay et al. (2003), Lindsay et al. (2005), Smith et al. (2013), Howe et al. (2014), and Boudon et al. (2017).

For this study we collected samples of pumice, ash, and lithic fragments from the lowermost two meters of the section leaving the uppermost six meters of the vertical face unsampled. Sampled pumice clasts and lithic fragments ranged from 6 to $15 \mathrm{~cm}$. Ash was scraped from the ignimbrite and sieved to $<2 \mathrm{~mm}$. 


\section{Laboratory}

Thin sections were prepared from the collected pumice samples. To establish mineral abundances 1500 grain point counts were done on thin sections from Fond St. Jean and Grand Bay. The remaining pumice, lithic, and ash samples were powdered for analysis of major and trace elements. In total, fifteen pumice clasts from Fond St. Jean and twenty-two pumice samples from Grand Bay were analyzed for major and minor elements. Trace element analysis was completed at Union College by ICPMS following guidelines of the ICP-MS analytical facility (Hollocher, 2016). Major element analysis was completed at Acme Labs via ICP-OES.

\section{SEM}

We analyzed carbon coated thin sections of pumice taken from the lowermost two meters at Fond St. Jean and representative Grand Bay samples using a Zeiss EVO-MA15 Scanning Electron Microscope (SEM) at Union College and a JEOL JSM-6610LV SEM at Macalester College. Analyses focused on titanomagnetite, ilmenite, orthopyroxene, clinopyroxene, and plagioclase with slightly differing beam conditions for each group. For the oxide minerals, we used an accelerating voltage of $20 \mathrm{kV}$ and beam current of $1.75 \mathrm{nA}$. Pyroxene, plagioclase, and glass were analyzed using $10 \mathrm{kV}$ and $1.00 \mathrm{nA}$. Each grain analysis reflects the average of fifteen short (5-10 sec duration; from which we used V, Mn, Ni, $\mathrm{Zn}$ ) and three long (45-50 sec; from which we used $\mathrm{Si}$, $\mathrm{Ti}, \mathrm{Al}, \mathrm{Fe}, \mathrm{Mg}, \mathrm{Ca}$ ) raster analyses. Sample analyses were corrected for beam drift using correction factors determined by comparison of measured and published values for Smithsonian mineral standards (Jarosweich et al. 1980) (Ilmenite, Roberts Victor Mine Garnet, Rockport Fayalite, Kakanui Augite, Natural Bridge Diopside, Plagioclase, Johnstown Hypersthene, Great Sitkin Island Anorthite) and Taylor mineral standards (V, Cr, Ni, Mn, Zn).

\section{RESULTS}

\section{Field}

The lowermost four meters of this section, beginning immediately on the southwestern side of town, are composed of six layers of largely matrix dominated block and ash flows with lithic clasts and volcanic bombs (1-50 $\mathrm{cm}$ in diameter). Overlying these are three, one-meter thick basalt flows that range in vesicularity from $5 \%$ (middle flow) to $50 \%$ (lower and upper flows). Above the basalt flows are thin ash laminations $(<0.2 \mathrm{~m}$ thick), which drape over blocks $(40-50 \mathrm{~cm})$ of the vesicular basalt from the underlying layer. A massive scoria deposit $(<4 \mathrm{~cm}$ diameter clasts) spans the next two meters and is overlain by approximately 3 meters intensely weathered material. Above the weathered profile is four meters of reworked and largely unconsolidated volcanic materials.

The ignimbrite overlies the reworked materials on a sharp unconformable contact and spans 8 meters before being overwhelmed by vegetation. The ignimbrite can be divided into 8 horizons (A through $\mathrm{H}$ in ascending order; Figure 1). Beginning at the base of the ignimbrite (13 meters above the base of the section), Horizon A is a one meter thick clastsupported ignimbrite consisting of $75 \%$ pumice clasts (5-7 $\mathrm{cm}$ diameter) and 3-5\% lithic clasts $(<1 \mathrm{~cm}$ diameter) in an ash matrix (20\%). The final $0.2 \mathrm{~m}$ of the bed transitions to laminations of ash. Horizon B (1.2 meters thick) is similar to Horizon A, but the ash laminations constitute a greater thickness $(0.4 \mathrm{~m})$. Horizons $\mathrm{C}, \mathrm{B}$, and $\mathrm{D}$ all consist of pumice dominated ignimbrite followed by ash dominated ignimbrite but with varying thicknesses of each layer (Figure 1). Horizon $\mathrm{E}$, is comprised of $0.6 \mathrm{~m}$ of pumice rich ignimbrite, however, it contains up to $10 \%$ lithic fragments and $65-70 \%$ pumice. Horizon $\mathrm{F}$ and horizon $\mathrm{G}$ are two additional expressions of pumice dominated ignimbrite followed by an ash dominated layer. Horizon $\mathrm{F}$ is $0.8 \mathrm{~m}$ of ignimbrite with $75 \%$ pumice clasts and 3-5\% lithic clasts (less than the previous horizons).

\section{Petrographic Analysis}

An analysis of four thin sections of representative samples from the lowermost two meters of ignimbrite at Fond St. Jean (Figure 2A) consist mostly of glass $(63 \%)$, with minor vesicles $(20 \%)$ and mineral grains (17\%). Mineral abundances at Fond St. Jean, renormalized to exclude glass and vesicles, include $80 \%$ plagioclase, $8 \%$ orthopyroxene, $2 \%$ 


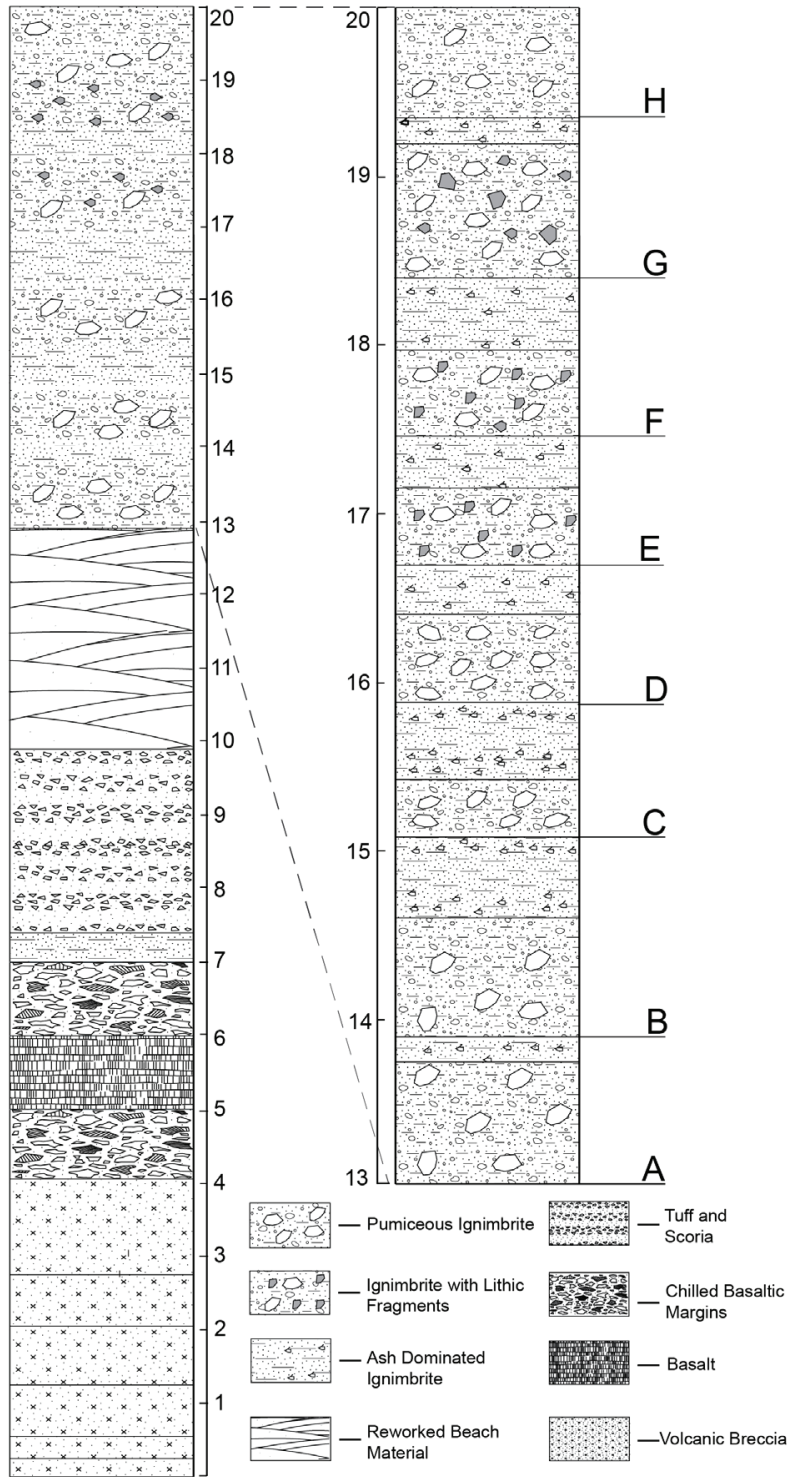

Figure 1. Stratigraphic column of exposed volcanic materials at Fond St. Jean (left). Exposed in the uppermost 7 meters of the section (13-20 $m$ above base), the ignimbrite at Fond St. Jean (enlarged on the right), consists mostly of reversely graded beds composed of pumice clasts, lithic clasts, and ash.

clinopyroxene, $6 \% \mathrm{Fe}-\mathrm{Ti}$ oxides, and 4\% hornblende. Four thin sections from Grand Bay (Figure 2B) were examined and consist on average of $63 \%$ glass, $10 \%$ vesicles, and $27 \%$ crystal grains. At Grand Bay, mineral re-normalized mineral abundances are $81 \%$ plagioclase, $11 \%$ orthopyroxene, $4 \%$ clinopyroxene, $4 \%$ and $\mathrm{Fe}-\mathrm{Ti}$ oxides.

\section{Mineral Compositions}

Plagioclase phenocrysts $(n=10)$ from Fond St. Jean have compositions that vary in anorthite content
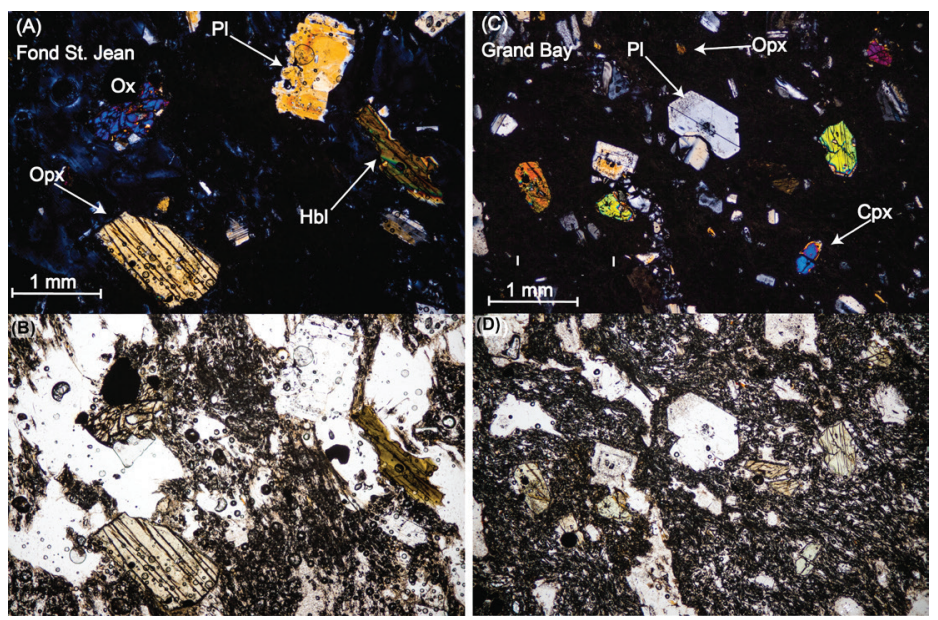

Figure 2. Photomicrographs of cross polarized (A and $C)$ and plain ( $B$ and $D)$ of ignimbrite from Fond St. Jean ( $A$ and $B)$ and Grand Bay (C and D) showing plagioclase (Pl), orthopyroxene $(O p x)$, clinopyroxene (Cpx), and oxides $(O x)$ in samples from both localities, in addition to hornblende ( $\mathrm{Hbl}$ ) at Fond St. Jean. Samples from Fond St. Jean are more vesicular and less crystal rich than those from Grand Bay.

$\left(A n_{57-78}\right)$. The cores of phenocrysts average $\mathrm{An}_{58-72}$ and are generally more calcic than the rims $\left(\mathrm{An}_{58-78}\right)$, indicating normal, although oscillatory, zoning. In contrast, Fond St. Jean pyroxene phenocrysts from four samples do not show evidence of compositional zonation; orthopyroxene compositions average $\mathrm{Wo}_{2} \mathrm{En}_{55}$ $\mathrm{Fs}_{42}$ and clinopyroxene averages $\mathrm{Wo}_{44} \mathrm{En}_{38} \mathrm{Fs}_{18}$. Magnetite phenocrysts from Fond St. Jean pumice clasts $(\mathrm{n}=5)$ average $77.65 \mathrm{wt} \% \mathrm{FeO}^{\mathrm{t}}$ and $10.98 \% \mathrm{wt} \% \mathrm{TiO}_{2}$, and ilmenite compositions average $47.56 \mathrm{wt} \% \mathrm{FeOt}$ and $46.20 \mathrm{wt} \% \mathrm{TiO}_{2}$. Plagioclase phenocrysts $(\mathrm{n}=10)$ from Grand Bay ignimbrite have core compositions that average $\mathrm{An}_{51-88}$ and are generally more calcic than the rims $\left(\mathrm{An}_{52-68}\right)$, indicating generally normal zoning. Grand Bay orthopyroxene compositions averaged from four samples are $\mathrm{Wo}_{2} \mathrm{En}_{55} \mathrm{Fs}_{42}$; clinopyroxene averages $\mathrm{Wo}_{43} \mathrm{En}_{38} \mathrm{Fs}_{19}$. Magnetite phenocrysts from Grand Bay pumice clasts have average compositions $(n=6)$ of $79.49 \% \mathrm{FeO}^{t}$ and $10.04 \% \mathrm{TiO}_{2}$; ilmenite compositions average $48.97 \% \mathrm{FeO}^{t}$ and $46.49 \% \mathrm{TiO}_{2}$.

\section{Whole Rock Geochemistry}

Whole rock analyses of Fond St. Jean pumice clasts $(\mathrm{n}=15)$ form high (63.0 to $\left.64.5 \mathrm{wt} \% \mathrm{SiO}_{2}\right)$ and low ( 60.5 to $62 \% \mathrm{wt} \% \mathrm{SiO}_{2}$ ) clusters based on silica content (Figure 3). Fond St. Jean samples also show higher $\mathrm{wt} \% \mathrm{~K}_{2} \mathrm{O}(1.7 \%)$ and $\mathrm{Al}_{2} \mathrm{O}_{3}(18.0 \%)$, and lower wt $\% \mathrm{Fe}_{2} \mathrm{O}_{3}{ }^{\mathrm{t}}(5.5 \%), \mathrm{MgO}(1.7 \%), \mathrm{Na}_{2} \mathrm{O}(3.1 \%)$, and 
$\mathrm{TiO}_{2}(0.5 \%)$ than samples from Grand Bay. Lithic clasts have greater amounts of $\mathrm{MgO}(4.5 \%)$ relative to ash $(2.5 \%)$, pumice clasts $(1.5 \%)$, and pumice glass $(0.2 \%)$. Lithic clasts and ash are basaltic (49-51\% wt $\% \mathrm{SiO}_{2}$ ), while glass from pumice clasts is rhyolitic $\left(75-76 \%\right.$ wt \% $\left.\mathrm{SiO}_{2}\right)$ (Figure 5A). Trace element compositions (e.g., Rb, Zr, REE) do not exhibit the same bimodal clustering demonstrated by silica and some major elements and in general are less enriched in incompatible trace elements compared to Grand Bay (Figure 5B and 5C). The REE patterns of Fond St. Jean pumice are LREE-enriched, have a distinct negative $\mathrm{Eu}$ anomalies $\left(\mathrm{Eu} / \mathrm{Eu}^{*}=0.70-0.90\right)$, and have spoon-shaped HREEs.

Whole rock analyses of Grand Bay pumice clasts $(\mathrm{n}=22)$ exhibit more limited silica contents $(61.2$ to $\left.63.4 \mathrm{wt} \% \mathrm{SiO}_{2}\right)$, higher $\mathrm{wt} \% \mathrm{Fe}_{2} \mathrm{O}_{3}{ }^{\mathrm{t}}(6.3 \%), \mathrm{MgO}$ $(2.3 \%), \mathrm{Na}_{2} \mathrm{O}(3.4 \%)$, and $\mathrm{TiO}_{2}(0.5 \%)$, and lower wt $\% \mathrm{~K}_{2} \mathrm{O}(1.5 \%)$ and $\mathrm{Al}_{2} \mathrm{O}_{3}(16.8 \%)$ when compared with Fond St. Jean samples (Figure 3A-F). In general, incompatible trace elements are more enriched in ignimbrite samples from Fond St. Jean compared with Grand Bay (Figure 5B, 5C). Ash has greater amounts of $\mathrm{MgO}(3.2 \%)$ relative to pumice clasts $(2.2 \%)$ and pumice glass $(0.05 \%)$, however, ash is basaltic andesitic in composition $\left(56 \% \mathrm{wt} \% \mathrm{SiO}_{2}\right)$, whereas pumice glass is rhyolitic $\left(79-80 \% \mathrm{wt} \% \mathrm{SiO}_{2}\right)$ (Figure $\left.5 \mathrm{~A}\right)$.

Grand Bay pumice samples have LREE-enriched patterns similar to Fond St. Jean, but with less negative Eu anomalies $\left(\mathrm{Eu} / \mathrm{Eu}^{*}=0.82-0.95\right)$.

\section{DISCUSSION AND CONCLUSIONS}

Ignimbrite deposits across Dominica can be difficult to compare because of the relative homogeneity of their stratigraphic and geochemical signatures. However, Lindsay et al. (2003) described differences between the ignimbrites at Fond St. Jean and Grand Bay when he suggested the Fond St. Jean ignimbrite to be the result of a more evolved magmatic system than Grand Bay. Recent work (Smith et al., 2003; Boudon et al., 2003) has called this association into question, though no detailed studies have been conducted aside from this one. Our results advance the calls for disassociation based on in depth stratigraphic and geochemical disparities.

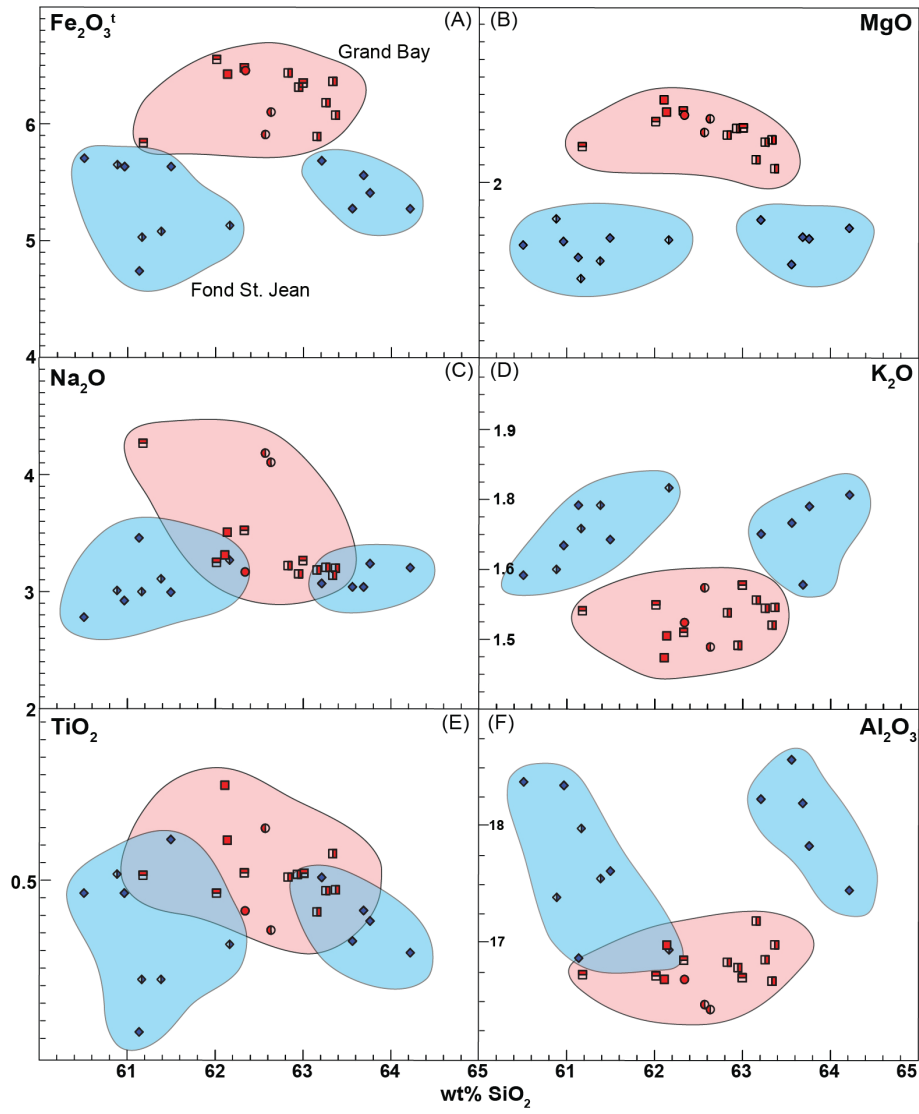

Figure 3. Major element Harker plots of Fond St. Jean (blue diamonds and shading) and Grand Bay (red squares and shading) pumice clasts. Note, at Fond St. Jean silica clusters tend not to correlate with changes in other major element concentrations.

If the ignimbrite at Fond St. Jean is a lateral equivalent of the Grand Bay ignimbrite, then the two should share common stratigraphic features, with some dissimilarities owed to distance from source. However, stratigraphic evidence from this study suggests there is little to no resemblance between the ignimbrites at Fond St. Jean and Grand Bay. At Fond St. Jean, normally graded ignimbrite beds of pumice clasts, lithic clasts, and ash are evidence of pulsating magmatism (Figure 1). In contrast, the massive and unsorted nature of both outcrops of the Grand Bay ignimbrite suggest a single large eruptive event.

If the ignimbrites at Fond St. Jean and Grand Bay were erupted from the same magma chamber and during the same event, then minerals in both should share similar growth conditions and histories. Although samples from both ignimbrites contain similar amounts of glass $(62-63 \%)$, Fond St. Jean samples were more vesicular (19.7\% versus $9.6 \%$, respectively) and less 


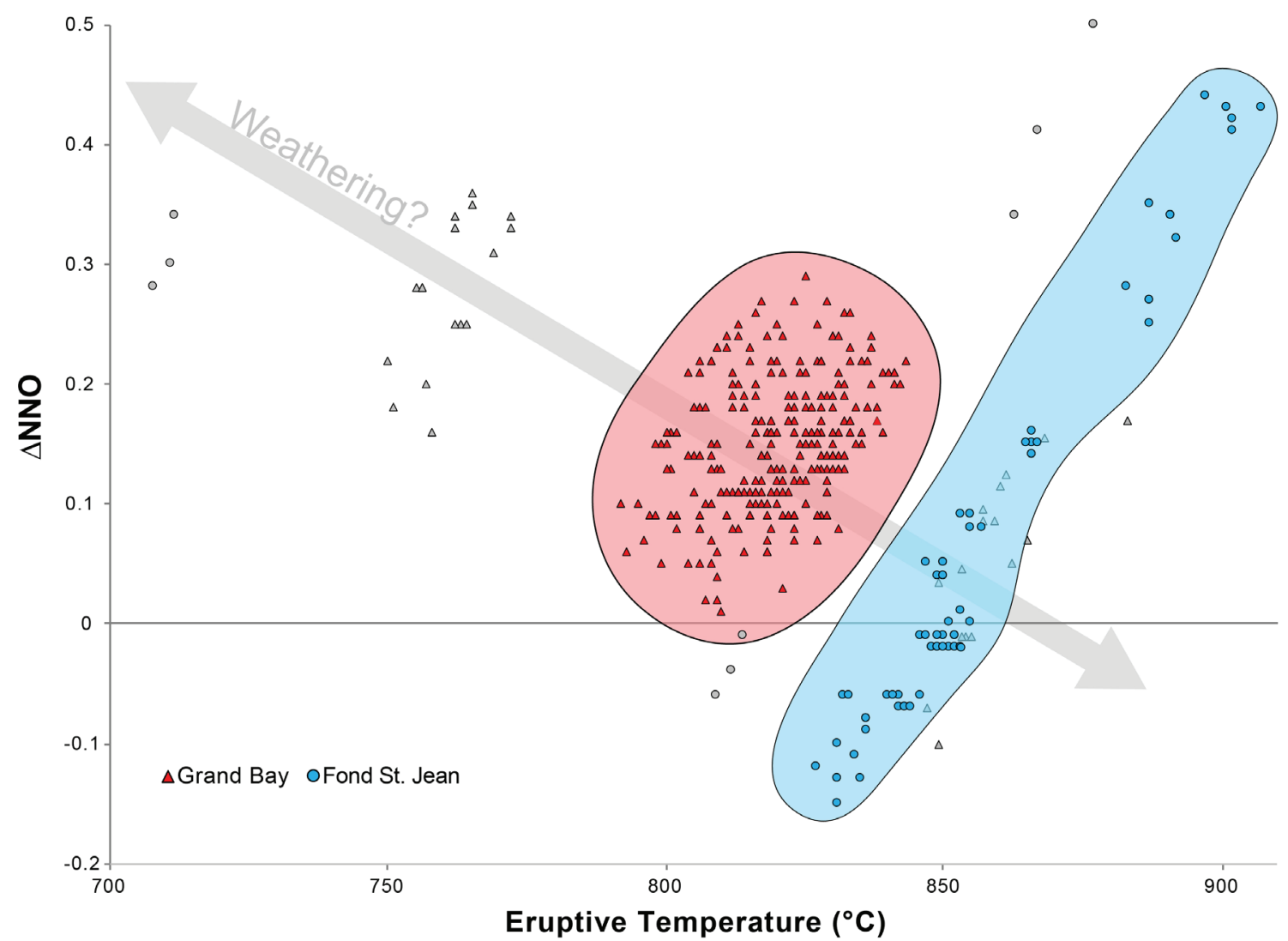

Figure 4. Clusters of magnetite-ilmenite derived eruptive temperatures from pumice samples of Fond St. Jean (blue) and Grand Bay (red). Mineral pairs from Fond St. Jean display an average temperature of $860 \pm 21{ }^{\circ} \mathrm{C}$ $(\triangle N N O=0.07)$, while those from Grand Bay average $822+13{ }^{\circ} \mathrm{C}(\triangle N N O=0.15)$. Oxide pairs that did not pass the Bacon and Hirschmann test of equilibrium (1988) (gray) were not included in average values.

crystal rich (17\% versus $27 \%$, respectively) than those from Grand Bay. While mineral phases and abundances are roughly similar, the ubiquitous presence of amphibole at Fond St. Jean is distinct given its total absence in Grand Bay pumice clasts. Plagioclase crystals at both localities exhibit oscillatory zoning and anorthite compositions $\left(\mathrm{An}_{57-78}\right.$ versus $\mathrm{An}_{51-88}$, respectively) with significant overlap between Fond St. Jean and Grand Bay samples, and so do not illuminate the relationship between these two ignimbrites. Pyroxene and oxide compositions are also not helpful in this regard. The similar mineral compositions of the two ignimbrites suggest that even if deposits resulted from different eruptions, then they were likely derived from similar magmatic sources and processes.

Another valuable tool in distinguishing igneous deposits is two-oxide geothermobarometry, which we can use to infer temperature and oxygen fugacity relative to the nickel-nickel oxide buffer $(\triangle \mathrm{NNO})$ during mineral growth. Geothermobarometry performed on 74 magnetite-ilmenite pairs from Fond St. Jean display an average temperature of $860 \pm 21^{\circ} \mathrm{C}(\triangle \mathrm{NNO}=0.07)$ ranging from $830^{\circ} \mathrm{C}$ to $915^{\circ} \mathrm{C}(\Delta \mathrm{NNO}=-0.14$ to 0.44$)$ (Figure 4$) . \mathrm{Fe}-\mathrm{Ti}$ pairs that did not pass the Bacon and Hirschmann test of equilibrium (1988) were not included in average values of temperature or fugacity (Figure 4). Temperatures derived from 291 magnetite-ilmenite pairs from Grand Bay average $822+13^{\circ} \mathrm{C}(\triangle \mathrm{NNO}=$ $0.15)$ trending from $792{ }^{\circ} \mathrm{C}$ to $844{ }^{\circ} \mathrm{C}(\Delta \mathrm{NNO}=0.01$ to 0.29 ). While both Fond St. Jean oxide pairs exhibit a positive trend in temperature and oxygen fugacity, temperatures at Fond St. Jean were notably higher than those from Grand Bay.

Plagioclase hygrometry, using the method of Waters and Lange (2015), allows insight into water contents of the source magma. Hygrometry reveals slightly drier magmatic conditions at Fond St. Jean (7.3 to 7.1 

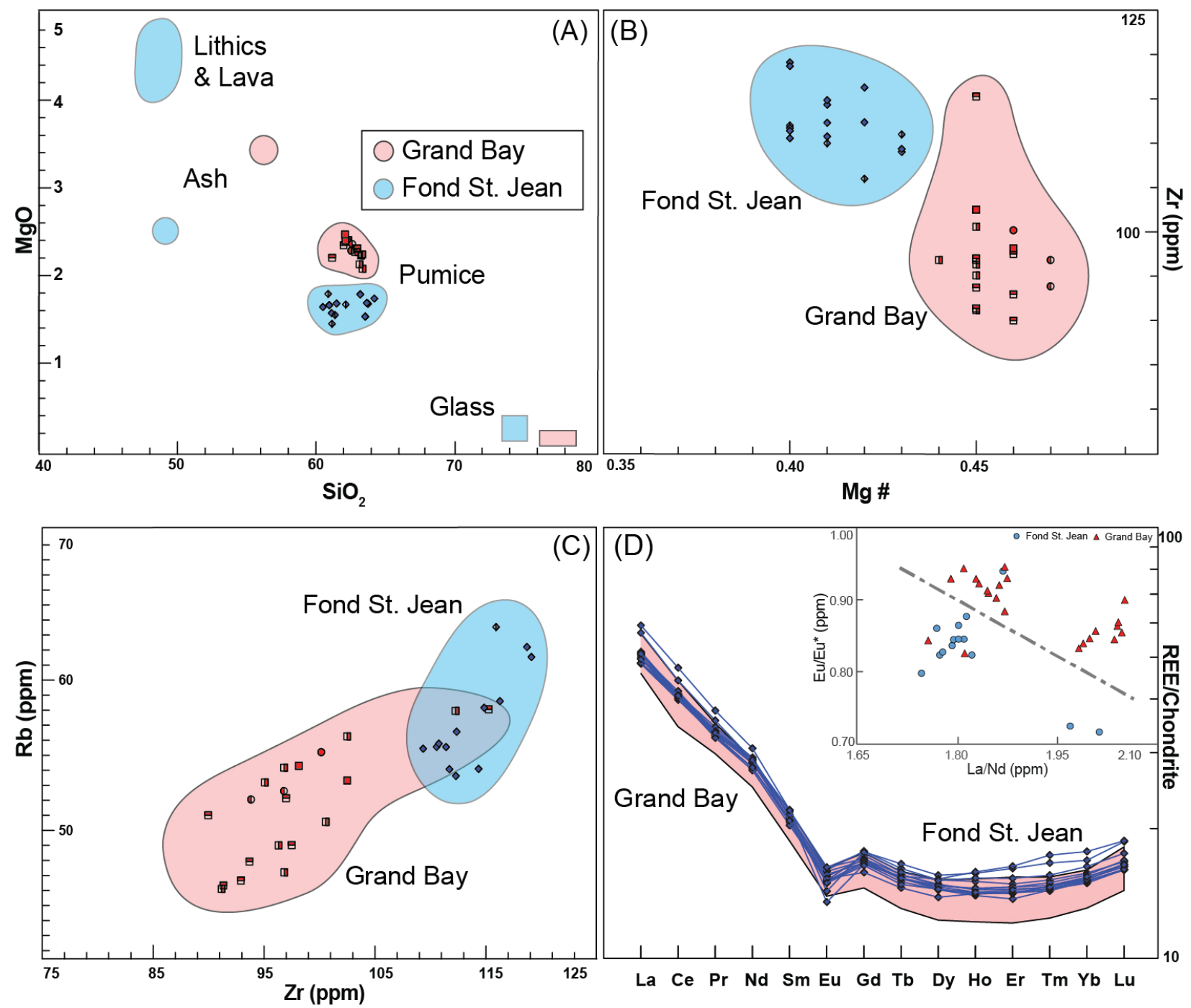

Figure 5. Whole rock geochemistry on ash, pumice and lithic clasts, and glass reveal separate groupings between Grand Bay and Fond St. Jean (A). Fond St. Jean has lower Mg \#s ([Mg]/[Mg + Fe+2]) and higher amounts of Zr relative to Grand Bay (B), as well as generally greater concentrations of $R b$ and $Z r(C)$. REE elements show similar patterns between the two ignimbrites (D) though Fond St. Jean samples exhibit generally lower La/Nd and lower Eu anomalies than those from Grand Bay ( $E u / E u^{*}=0.7$ to 0.9 and 0.82 to 0.95 , respectively) at a given concentration of La/Nd (D inset).

wt $\% \mathrm{H}_{2} \mathrm{O}$ ) compared to those at Grand Bay (7.8 to 7.3 wt $\left.\% \mathrm{H}_{2} \mathrm{O}\right)$. However, these differences are slight and may not be significant given the relatively large errors in these measurements. Interestingly, the drier conditions implied by hygrometry for Fond St. Jean, relative to Grand Bay, seem counterintuitive given the presence of amphibole at Fond St. Jean.

Whole rock geochemistry reveals that the ignimbrites at Fond St. John and Grand Bay have distinct chemical fingerprints. Where Fond St. Jean samples exhibit high and low silica components, those from Grand Bay plot as a single intermediate group. Furthermore,
Fond St. Jean pumice glass compositions are less siliceous than those from Grand Bay $(75-76 \%$ and $79-$ $80 \% \mathrm{wt} \% \mathrm{SiO}_{2}$, respectively), and so must come from different magmatic sources. Overall, Fond St. Jean samples are less enriched in compatible major elements (e.g., $\mathrm{Fe}_{2} \mathrm{O}_{3}{ }^{\mathrm{t}}$ and $\mathrm{MgO}$; Figure 3) suggesting that it was derived from a more evolved magmatic system. Analyses of incompatible trace elements (e.g., Zr, Rb) reveal a similar story; Fond St. Jean pumice samples consistently exhibit higher incompatible trace element abundances at a given $\mathrm{Mg} \#$ (Figure 5B, 5C). REE patterns are very similar between the Fond St. Jean and Grand Bay ignimbrites, however, Fond 
St. Jean samples generally exhibit lower $\mathrm{La} / \mathrm{Nd}$ and more negative $\mathrm{Eu}$ anomalies $\left(\mathrm{Eu} / \mathrm{Eu}^{*}=0.7\right.$ to 0.9 and 0.82 to 0.95 , respectively) at a given level of LREE enrichment (Figure 5D). The lower Eu abundances at Fond St. Jean could be the result of greater plagioclase fractionation, either during melting in the source or during crystallization in a magma chamber, or to varying degrees of crustal contamination.

In summary, significant differences in stratigraphy, mineralogy, mineral chemistry, and whole-rock compositions suggest that the similarly aged ignimbrites at Fond St. Jean and Grand Bay likely stem from different eruptive events. However, similarities in mineral abundances and compositions do not preclude derivation of these two ignimbrites from different batches of magma at a shared volcanic source. Disassociation of these two ignimbrites also calls into question whether other ignimbrites along the southeastern coast (e.g., Petit Savane; Boudon et al., 2017) might also represent additional eruptive events. If an inland, more proximal, expression of the Fond St. Jean ignimbrite can be located, it might help to further illuminate the origin of this eruption.

\section{ACKNOWLEDGEMENTS}

This material is based upon work supported by the Keck Geology Consortium and the National Science Foundation under Grant No. 1659322. Thank you to Holli Frey and Karl Wirth for your guidance and enthusiasm every step of the way. Many thanks to Laura Waters, Amanda Schmidt, and Pat Joseph for your help on Dominica and beyond. This project could not have been completed without the assistance and support of Jeff Thole, Matthew Manon, Bill Neubeck, all of my Keck peers, and of course the staff of the Archbold Tropical Research and Education Center in Dominica.

\section{REFERENCES}

Bacon, C.R., and Hirschmann, M.M., 1988, Mg/Mn Partitioning As a Test for Equilibrium between Coexisting Fe-Ti Oxides. American Mineralogist, 73(1-2), 1-200.

Boudon, G., Balcone-Boissard, H., Solaro, C., and Martel, C., 2017, Revised chronostratigraphy of recurrent ignimbritic eruptions in Dominica (Lesser antilles arc): Implications on the behavior of the magma plumbing system. Journal of Volcanology and Geothermal Research, 343, 135-154. doi:10.1016/j.jvolgeores.2017.06.022

Carey, S.N., and Sigurdsson, H., 1980, The Roseau ash: deep-sea tephra deposits from a major eruption on Dominica, Lesser Antilles arc. Journal of Volcanology and Geothermal Research 7: 67-86.

Frey, H.M., Manon, M.R.F., Brehm, S., Babiak, R., 2016, The U-Th zircon chornology revelas protracted cold storage and subsequent rejuvenation in magma reservoirs beneath Dominica, Lesser Antilles, Abstract [V53D-315] presented at the 2016 Fall Meeting, AGU, San Francisco, Calif., 12-16 Dec.

Ghiorso, M.S., and Evans, B.W., 2008, Thermodynamics of rhombohedral oxide solid solutions and a revision of the Fe-Ti twooxide geothermometer and oxygen-barometer. American Journal of Science, 308(9), 957-1039. doi:10.2475/09.2008.01

Hollocher, K., 2016, ICP-MS Analytical Facility, Retrieved on 3/19/2018 from http://minerva. union.edu/hollochk/icp-ms/index.html

Howe, T.M., Lindsay, J.M., Shane, P., Schmitt, A.K., and Stockli, D.F., 2014, Re-evaluation of the Roseau Tuff eruptive sequence and other Ignimbrites in Dominica, Lesser Antilles. Journal of Quaternary Science 29(6): 531-546.

Jarosewich, E., Nelen, J.A., and Norbers, J.A., 1980, Reference Samples for Electron Microprobe Analysis. Geostandards Newsletter, 4(1), 43-47. doi:10.1007/s00445-002-0253-y 
Lindsay, J., Stasiuk, M., \& Shepherd, J., 2003, Geological history and potential hazards of the late-Pleistocene to recent plat pays volcanic complex, Dominica, Lesser Antilles. Bulletin of Volcanology, 65(2-3), 201-220. doi:10.1007/ s00445-002-0253-y

Lindsay, J.M., Smith, A.L., Roobol, M.J., and Stasiuk, M.V., 2005, Dominica: Volcanic Hazards of the Lesser Antilles. Seismic Research Unit, The University of the West Indies, Trinidad and Tobago.

Smith, A., Roobol, M.J., Mattioli, G., Fryxell, J., Daly, G., Fernandez, L.A., 2013, The Volcanic Geology of the Mid-Arc Island of Dominica, Lesser Antilles-The Surface Expression of an Island-Arc Batholith. Special Paper of the Geological Society of America. 496. 249. 10.1130/2013.2496.

Union College ICP-MS Analytical Facility. Retrevied on 3/19/18 from http://minerva.union.edu/ hollochk/icp-ms/index.html

Waters, L. E., \& Lange, R. A., 2015, An updated calibration of the plagioclase-liquid hygrometerthermometer applicable to basalts through rhyolites. American Mineralogist, 100(10), 21722184. DOI: $10.2138 / \mathrm{am}-2015-5232$. 